\title{
Diaspora ortodoxă română în Italia: strategii și dinamici în crearea și folosirea lăcașurilor de cult
}

\author{
Ioan COZMA* \\ Maria Chiara GIORDA**
}

\begin{abstract}
The Romanian Orthodox Diaspora in Italy: Strategies and Dynamics in Establishing and Use of Places of Worship. This paper presents the reality of religious diversity in contemporary Italy, which has in its center one of the largest and most mediatized religious and ethnic groups, that is, the Orthodox Romanians. In the last decade, this religious group has undergone an extensive process of stabilization and settling, which is visible both in material (through the purchase or construction of their own places of worship) and demographic terms (through the growing number of those who apply for Italian citizenship). Despite the number of believers and the multitude of parishes, this religious group still has difficulties building its own places of worship because they are not recognized as religious entities by the Italian state. Based on some representative examples, the article focuses primarily on the dynamics and strategies of establishing and managing the places of worship of Romanian Orthodox parishes. We use an interdisciplinary method, combining historical, social, and ethnographic tools.
\end{abstract}

Keywords: Romanian Orthodox Diaspora, religious diversity, shared religious places, places of worship, Italy.

\section{Introducere}

Italia a cunoscut în ultimele decenii o prezență tot mai notabilă a spiritualității creștine ortodoxe ca urmare a faptului că tot

* Preot, profesor universitar la Institutul Pontifical Oriental din Roma, Italia.

** Profesor universitar la Departamentul de Științe Umaniste, Universitatea Roma Tre din Roma, Italia. 
mai mulți emigranţi ce aparțin acestui spațiu spiritual s-au stabilit în această țară. Fenomenul declanșat de fluxurile migratorii, care continuă să transforme profund țesutul social și cultural al Italiei, a contribuit la modificarea profilului confesional din peninsulă, dominat totuşi de prezența Bisericii Romano-Catolice. Această situație, cunoscută sub numele de Noul Pluralism Religios ${ }^{1}$, pare să treacă neobservată în sfera discursurilor politice (sau este în mod intenţionat evitată), nu însă în aceea a analizei și dezbaterilor academice: atât cercetătorii italieni, cât și cei străini au dedicat în ultimele decenii studii importante pluralismului şi (super)diversității religioase din Italia. În ceea ce privește Ortodoxia și prezența sa instituţională în peninsulă, se remarcă cu precădere studiile unor autori ca Cesare Alzati, Gino Battaglia, Luigi Berzano, Andrea Cassinasco, Pietro Cingolani, Giuseppe Giordan, Suna Gülfer Ihlamur-Öner, Marco Guglielmi, Enrico Morini, Andrea Longhi, Andrea Pacini, Vittorio Parlato și Mikhail Talalay². De

* Acest studiu face parte dintr-un proiect de cercetare mai amplu privind locaşurile de cult ale parohiilor ortodoxe românești din Italia, inițiat în 2018. Fragmente din acest articol au fost deja publicate în limba italiană în: Maria Chiara Giorda / Ioan Cozma (eds.), Ortodossi romeni d'Italia, în Quaderni di Benvenuti in Italia, 13 (2018); IDEM, ,Sostituire, condividere, costruire: le parrocchie ortodosse romene nel tortuoso cammino verso il riconoscimento", în Religione e Società, 35: 96 (2020), p. 23-32; IDEM, „Luoghi di culto della Chiesa ortodossa romena in Italia: dinamiche di insediamento" (în curs de publicare).

${ }^{1}$ A se vedea Fabbio Ballabio / Brunetto Savarani (eds.), Religioni in Italia: Il Nuovo Pluralismo Religioso, Bologna, Editrice Missionaria Italiana, 2011.

2 Cesare Alzati, „L'Ortodossia nello spazio romeno e il significato della sua presenza in Italia per la Comunione tra le Chiese", în Gino Battaglia (ed.), L'Ortodossia in Italia: le sfide di un incontro, Bologna, Edizioni Dehoniane, 2011, p. 171-198; Luigi BERZANo / Andrea CASSINASCO, Cristiani d'Oriente in Piemonte, Torino, L'Harmattan, 1999; Pietro Cingolani, Romeni d'Italia, Bologna, Mulino 2009; Giuseppe Giordan, „La costellazione delle Chiese ortodosse", în Enzo Pace (ed.), Le religioni nell'Italia che cambia. Mappe e bussole, Roma, Carrocci, 2013, p. 13-30; IDEM, „A world in motion: The plurality of orthodox churches in Italy", în Giuseppe Giordan / William H. 
asemenea, sunt de remarcat cercetări sociologice, antropologice și etnografice în domeniul pluralismului religios, cum ar fi cele efectuate de laboratorul Vivere le religioni din Torino, coordonat de profesorii Maria Chiara Giorda și Luca Bossi ${ }^{3}$ și cele ale Observatorului Pluralismului Religios (Osservatorio per il pluralismo religioso) din Bologna, inițiat și coordonat de Giuseppe Ferrati, Pino Trombetta și Luigi Berzano ${ }^{4}$.

Swatos (eds.), Testing pluralism, globalizing belief, localizing Gods, Leiden, Brill, 2013, p. 57-74; IDEM, „Orthodox Christianity in Italy: Historical continuity and social discontinuity", în Religion, State \& Society, 43 (2015), p. 262-275; Giuseppe Giordan / Marco GugliElmi, „Be fruitful and multiply... Fast! The Spread of Orthodox Churches in Italy", în Jörg Stolz / Christophe Monnot (eds.), Congregations in Europe, Cham, Springer, 2018, p. 53-69; Marco Guglielmi, „Globalization and Orthodox Christianity: A Glocal Perspective”, în Religions, 9: 7 (2018): la https://www.mdpi.com/2077-1444/9/7/216/htm (27.08.2021); Suna Gülfer IHLAMUR-ÖNER, ,, Romanian Orthodox Churches in Italy: The Construction of the Romanian-Italian Transnational Orthodox Space", în Maria Hämmerli / Jean-François Mayer (eds.), Orthodox Identities in Western Europe: Migration, Settlement and Innovation, London / New York, Routledge, 2014, p. 29-50; Enrico Morini, Gli ortodossi, Bologna, Il Mulino, Edizione E-book, 2010; Andrea PACINI, „L'ortodossia in Europa e nel mondo: profilo demografico e organizzazione ecclesiale", în Andrea Pacini (ed.), L'Ortodossia nella nuova Europa. Dinamiche storiche e prospettive, Torino, Edizioni della Fondazione Giovanni Agnelli, 2003, p. 165-184; Vittorio PARLATO, „Gli edifici di culto ortodossi in Italia come testimonianze della fede, delle memorie e cultura di popoli", în Stato, Chiese e pluralismo confessionale, 32 (2019), p. 126-137; Mikhail TALALAY, „Ortodossia russa in Italia”, în Religioni e società, 30 (1998), p. 90-98.

3 http://www.interculturatorino.it/formazione/vivere-le-religioni-a-torino-2015/ (16. 09.2021).

4 https://www.osservatoriopr.net/osservatoriopr/s2magazine/index1.jsp?idPagina=2 (16.09.2021). Printre rezultatele acestui centru amintim următoarele studii: Assemblea legislativa Regione Emilia-Romagna (ed.), I monoteismi in EmiliaRomagna: Ebraismo, Cristianesimo ortodosso, Islam, Bologna, 2017; Davide N. CARneVale / Simona F. GîRnEȚĂ, Aspettative e bisogni delle comunità religiose a Bologna - Le chiese ortodosse, Bologna, Comune di Bologna - AMITIE code, 
Statisticile în domeniu, în principal estimările elaborate de Centrul de Studii și Cercetări IDOS în parteneriat cu Centrul de Studii Confronti (2020), arată că din numărul total de străini aparținând confesiunilor creștine $(2.749 .000$ din totalul de 5.039.637 emigranți, adică 51,9\%), majoritatea sunt de credință ortodoxă $(54,5 \% \text {, adică peste } 1.532 .000 \text { de persoane })^{5}$. Aceste cifre rămân chestionabile, deoarece se estimează că un număr de aproximativ 200.000 de emigranți au părăsit Italia numai în anul 2020 datorită situaţiei economice create de pandemia Covid-196 ${ }^{6}$.

Este important să subliniem faptul că în categoria „creștinilor ortodocşi” statisticile includ credincioşii şi clericii apartenenți Bisericilor ortodoxe canonice (Patriarhia Ecumenică, Patriarhia de Antiohia, Patriarhia Moscovei, Patriarhia Sârbă, Patriarhia Română, Patriarhia Bulgară, Patriarhia Georgiei), pe cei ai Bisericilor antice-orientale, numite adesea și ele „Biserici ortodoxe" (Biserica armeană, Biserica coptă, Biserica etiopiană, Biserica eritreeană, Biserica siro-iacobită), precum și pe cei care aparțin unor Biserici, structuri și grupări schismatice (semicanonice sau necanonice) care, sub diverse titulaturi, îşi se revendică apartenența la ortodoxie (cum ar fi Biserica ortodoxă autocefală din Macedonia de Nord; Biserica ortodoxă din Montenegro; Mitropolia de Milano și Aquileia; Biserica autonomă creștin ortodoxă de Bergamo și Europa; Biserica ortodoxă greacă după vechiul calendar; Biserica ortodoxă română după vechiul calendar; Biserica ortodoxă rusă de rit vechi; Biserica ortodoxă italiană autocefală vechi-orientală; Biserica ortodoxă din Italia; Biserica Veche-Catolică din Italia/Biserica ortodoxă în Italia-

2018; IDEM, Comunità Da Remoto. „Il Laboratorio Della Diaspora CristianoOrtodossa Davanti Alla Pandemia", în Comparative Cultural Studies - European and Latin American Perspectives, 6: 13 (2021), p. 143-164.

${ }^{5}$ Centro Studi e Ricerche IDOS și Centro Studi CONFRONTI (eds.), Dossier Statistico Immigrazione 2020, Roma, Centro Studi e ricerche IDOS, 2020, p. 231.

6 Pentru o comparație, a se vedea studiul Elena AdESSI / Alberto DEL Bove, L'impatto della pandemia sui beneficiari di accoglienza del Lazio meridionale, în Ginevra Demaio (ed.), Osservatorio sulle Migrazioni a Roma e nel Lazio. Sedicesimo Rapporto, Roma, Centro Studi e Ricerche IDOS, 2021, p. 52-56. 
Asociaţia „Mitropolitul Antonie”; Biserica ortodoxă italiană/Adevărata Biserică ortodoxă italiană; Biserica autonomă catolică ortodoxă din Italia și România; Episcopia din Italia Subalpină-Patriarhia ortodoxă de Europa; Biserica ortodoxă belorusă și slavă) ${ }^{7}$.

Scopul acestui studiu este de a ilustra realitatea superdiversității religioase din Italia contemporană, o realitate care are în centrul ei una dintre comunitățile religioase cele mai numeroase și mediatizate, și anume cea ortodoxă română. Această comunitate a cunoscut, cel puțin în ultimul deceniu, un proces amplu de stabilizare şi înrădăcinare, vizibil atât în termeni materiali - prin cumpărarea sau construirea propriilor locașuri de cult, cât și în termeni demografici prin numărul crescând, de la an la an, al celor care solicită și dobândesc cetățenia italiană. Studiul nostru se va concentra, în principal, pe prezentarea și analiza dinamicilor și strategiilor de constituire și funcționare ale locașurilor de cult din cadrul parohiilor și misiunilor ortodoxe românești, pe baza câtorva exemple reprezentative. În acest scop, vom folosi o metodă interdisciplinară, combinând instrumente și cunoștințe de natură istorică, socială și etnografică.

\section{Primele comunități parohiale ortodoxe în Italia}

Prezența ortodocșilor în Italia nu este o noutate în peisajul confesional italian, ci coboară până în perioada Imperiului Bizantin, ei fiind de cele mai multe ori identificați în documentele medievale şi moderne cu apelativul de ,greci”. Cu toate acestea, începuturile prezenței instituționale au fost înregistrate abia la 28 noiembrie 1498, dată la care comunitatea ortodoxă greacă din Republica Venețiană (estimată la circa 4000 persoane, în mare

${ }^{7}$ A se vedea Massimo InTrovigne / Pier Luigi ZocCARELli (eds.), Le Religioni in Italia. La Chiesa Ortodossa Italiana, disponibil la https://cesnur.com/la-chiesaortodossa-italiana/ (16.09.2021); Davide N. CARnEVALE, „I cristianesimi ortodossi in Emilia-Romagna: una mappatura", în Assemblea legislativa Regione Emilia-Romagna (ed.), I monoteismi in Emilia-Romagna..., p. 75-121. 
parte refugiați din fostele teritorii bizantine ocupate de otomani $\left.{ }^{8}\right)$ a primit permisiunea din partea guvernului Serenissimei (Sfatul celor zece) de a se organiza într-o fraternitate ortodoxă, Confraternitatea Greco-Ortodoxă „Sfântul Nicolae" (Confraternita dei Greci Ortodossi o di Nazione Greca di S. Nicola), care le permitea să aibă școală în limba greacă, precum și să țină slujbe în ritul ortodox bizantin ${ }^{9}$. În aceste circumstanțe, între 1539 și 1573 a fost construită prima biserică ortodoxă din peninsulă, și anume Biserica „Sfântul Gheorghe” (cunoscută până astăzi ca „Biserica Sf. Gheorghe a Grecilor”), situată în apropiere de Bazilica San Marco în Veneția, cu contribuția financiară a membrilor fraternitătii, precum și cu bani proveniţi din taxele impuse mărfurilor și corăbiilor din lumea ortodoxă ${ }^{10}$. Din anul 1573 până în 1790, Biserica „Sfântul Gheorghe” a fost și sediul arhiepiscopilor de Filadelfia ${ }^{11}$.

${ }^{8}$ În privința numărului și a locului de proveniență a emigranților de limbă greacă din Veneția, a se vedea Mathieu GRENET, „Naissance et affirmation d'une nation étrangère entre colonie et groupe de pression: le cas des Grecs à Venise entre le $\mathrm{XV}^{\mathrm{e}}$ et le $\mathrm{XVII}{ }^{\mathrm{e}}$ siècle", în Albrecht Burkardt (ed.), Commerce, voyage et expérience religieuse, $X V I^{e}-X V I I I^{e}$ siècles, Rennes, Presses Universitaires de Rennes, 2007, p. 419-438.

9 A se vedea Giorgio Fedalto, „La Comunità greca, La Chiesa di Venezia, La Chiesa di Roma”, în Maria F. Tiepolo / Eurigio Tonetti (eds.), I Greci a Venezia, Veneția, Istituto Veneto di Scienze Lettere ed Arti, 2002, p. 83-102; Nicholaos G. MoschonAs, „La Comunità greca di Venezia: aspetti sociali ed economici”, în Ibidem, p. 221-242; Donatella CALABI, ,L'insediamento greco e il contesto urbano", în Ibidem, p. 555-568.

${ }^{10}$ A se vedea Ersi Brouscari, „La chiesa di San Giorgio dei Greci a Venezia e l'architettura", în Maria F. Tiepolo / Eurigio Tonetti (eds.), I Greci a Venezia, p. 533-555.

${ }^{11}$ A se vedea Manoussos Manoussacas, „La comunità greca di Venezia e gli Arcivescovi di Filadelfia", în vol. La Chiesa greca in Italia dall'VIII al XVI secolo, Atti del Convegno storico interecclesiale (Bari, 30 aprile -4 maggio 1969), t. 1, Padova, Antenore, 1973, p. 45-87; Efstathios BIRTACHAS, „Un secondo" vescovo a Venezia: il metropolita di Filadelfia (secoli XVI-XVIII)", în Maria F. Tiepolo / Eurigio Tonetti (eds.), I Greci a Venezia, p. 103-122; Gino 
După modelul venețian, au fost fondate confraternități grecoortodoxe și în alte orașe cu importante comunități grecești: la Ancona, în anul 1531 este fondată Confraternitatea Greco-Ortodoxă „Sfânta Ana” (Confraternità greco-ortodossa di Sant'Anna), având ca sediu Biserica „Sfânta Ana”, aflată în uzul comunități grecoortodoxe încă din anul 1524 prin bula papei Clement al VII-lea; la Napoli a fost fondată, în 1536, Confraternitatea Greco-Ortodoxă „Sfinții Apostoli Petru și Pavel”, care în anul 1544, primește din partea papei Paul III dreptul de sluji în ritul greco-ortodox în Biserica „Sfinții Apostoli Petru și Pavel” (construită în anul 1518 prin contribuția principelui bizantin Toma Paleologul); la Livorno a fost fondată, în anul 1775, Confraternitatea Greco-Ortodoxă „Sfânta Treime" (Arciconfraternità greco-ortodossa della S. Trinità), având ca locaș de cult Biserica „Sfânta Treime”, construită de către comunitatea greco-ortodoxă în anul $1760 \mathrm{cu}$ aprobarea gran-ducelui Francisc I; la Trieste, în anul 1782, a fost fondată Confraternitatea Greco-Ortodoxă „Sfântul Nicolae” (Confraternità greco-ortodossa di S. Nicola), care între anii 1782 şi 1795, a construit biserica cu hramul „Sfântul Nicolae și Sfânta Treime"12.

Statutul Albertin din anul 1848 (adoptat de toate celelalte republici de dinaintea unificării) a recunoscut Catolicismul ca religie de stat și a stabilit, în același timp, principiul toleranței pentru toate cultele. De atunci și până astăzi în peninsulă,

BATTAGLIA, „Introduzione. La tradizione bizantina in Italia, tra fede e storia”, în Gino Battaglia (ed.), L'Ortodossia in Italia..., p. 1-29.

12 A se vedea istoria acestor confraternități la Luca PAOLINI, „La tolleranza religiosa garantita ai greci nella Livorno granducale", în Studi Urbinati. Nuova Serie, 57-58/41-42 (1988-1990), p. 217-246; Heleni PORFYRIOU, „La diaspora greca in Italia dopo la caduta di Costantinopoli: Ancona, Napoli, Livorno, e Genova", în Maria F. Tiepolo / Eurigio Tonetti (eds.), I Greci a Venezia, p. 151-184; IDEM, „La presenza greca in Italia: chiese, confraternità e collegi”, în Donatella Calabi / Elena Svalduz (eds.), Il Rinascimento italiano e l'Europa, vol. 6. Luoghi, spazi, architetture, Costabissara, Fondazione Cassamarca / Angelo Colla Editore, 2010, p. 567-584; Mathieu GrENET, La Fabrique Communautaire. Les Grecs à Venise, Livourne et Marseille, v. 1770-v.1830, Roma, École française de Rome / École française d'Athènes, 2016. 
parohiile și comunitățile greco-ortodoxe s-au înmulțit semnificativ, incluzând și mici centre monahale, totalizând în momentul de față un număr de 77 de locașuri de cult (66 de biserici parohiale, 7 mănăstiri și 4 sanctuare) $)^{13}$. Din anul 1991, ortodoxia greacă este organizată într-o arhiepiscopie, Arhiepiscopia Ortodoxă a Italiei și Exarhatul pentru Europa de Sud. Din data de 16 iulie 1998, arhiepiscopia a dobândit statut de persoană juridică, cu efecte civile în Italia, iar la data de 30 iulie 2012 a ratificat așa numita Intesa (acord) cu statul italian (Decretul-lege nr. 126/2012) prin care se bucură de o serie de drepturi printre care dreptul de a primi o parte din aşa numitul „otto per mille”, adică o parte din impozitele primite de la contribuabili pe care statul le oferă instituțiilor religioase ${ }^{14}$.

Pe lângă ortodocșii de limbă greacă, de la mijlocul secolului al XVIII-lea găsim indicii ale prezenței ortodoxe sârbe în partea de nord-est a Italiei, la Trieste, sub jurisdicția episcopului sârb de Karlovitz. În 1753, ca urmare a drepturilor acordate în imperiul Austro-Ungar de împărăteasa Maria Tereza în vederea construirii de biserici și mănăstiri pentru cultul ortodox, comunitatea ortodoxă sârbă și-a construit propria biserică la Trieste, cu hramul „Sfântul Spiridon"15. În prezent, în Italia funcționează 7 parohii ortodoxe sârbești (Trieste, Vicenza, Roma, Udine, Porcia, Milano, Genova)

${ }^{13}$ A se vedea lista parohiilor și a mănăstirilor la adresa: http://www.ortodossia.it/w/ index.php?option=com_content $\&$ view=category $\&$ layout=blog $\&$ id=30\&Itemid= 188\&lang=it (17.09.2021).

${ }^{14}$ Vittorio PARLATO, „La legge n. 126 del 2012 relativa ai rapporti tra Italia e Sacra Arcidiocesi Ortodossa d'Italia e Malta", în Stato, Chiese e pluralismo confessionale, 36 (2012), p. 1-19, disponibil la https://www.statoechiese.it/images/uploads/articoli_pdf/parlato3_la_legge.pdf?p df=la-legge-n.-126-del-2012-relativa-ai-rapporti-tra-italia-e-sacra-arcidioces (17.09.2021); Ioan COZMA / Maria Chiara GIORDA, „Per una storia della Chiesa ortodossa romena...”, p. 19; Giuseppe GIORDAN / Marco GuGLIELMI, „Be fruitful and multiply...”, p. 57.

15 Ioan Cozma / Maria Chiara GioRdA, „Per una storia della Chiesa ortodossa romena in Italia", în Quaderni di Benvenuti in Italia, 13, 2018, p. 19. 
organizate într-un protopopiat, sub jurisdicția canonică a Eparhiei Ortodoxe Sârbe din Austria, Elveția, Italia și Malta ${ }^{16}$.

O altă prezență ortodoxă veche pe teritoriul Italiei este cea a Bisericii ortodoxe ruse. Primele informații despre un loc de cult rusesc le avem în anul 1791: este vorba de o capelă ortodoxă amenajată la Torino, în incinta ambasadei rusești din Regatul Sardiniei. O tentativă similară a urmat pentru scurt timp în 1802 la ambasada rusă din Napoli. În 1823 a fost înființată în incinta misiunii diplomatice rusești din Roma o capelă dedicată Sfântului Nicolae Taumaturgul. Instaurarea regimului bolșevic în Rusia a dus la mutarea locului de slujire din cadrul ambasadei ruse: în anul 1929, cu sprijinul unor familii ruse din Roma și împrejurimi, parohia primește un nou sediu, construit în incinta palatului principesei Chernisheva (pe Via Palestro) ${ }^{17}$. La sfârşitul secolului al XIX-lea și începutul secolului al XX-lea au fost înființate parohii și au fost construite biserici la Merano (1898), Florența (1903), Sanremo (1913) şi Bari (1913) ${ }^{18}$. În prezent, Patriarhia Moscovei are în Italia două stavropighii și 59 de parohii, organizate într-un vicariat cu sediul la Roma (Biserica „Sfânta Ecaterina", construită pe teritoriul Ambasadei ruse) ${ }^{19}$, aflat sub administrarea mitropolitului de Chersones (cu sediul la Paris), care este și exarh pentru Europa Occidentală și, totodată, administrator al parohiilor din Italia $^{20}$. La acestea se adaugă și Parohia „Sfântul Nicolae” de la Bari a Bisericii Ortodoxe Ruse din străinătate (ROCOR), aflată sub jurisdicția episcopului rus de Geneva, care depinde de Patriarhia Moscovei ${ }^{21}$.

${ }^{16}$ Date despre parohiile ortodoxe sârbești din Italia se găsesc la adresa http://www. crkva.at/de/pfarren/italien-malta/ (17.09.2021).

${ }^{17}$ Gino BatTaglia, „Introduzione. La tradizione bizantina...”, p. 22.

${ }^{18}$ Michail TALALAY, ,Ortodossia russa in Italia”, p. 94.

${ }^{19}$ Vittorio PARLATO, „Gli edifici di culto ortodossi in Italia...”, p. 131-132.

20 Informații despre organizarea parohiilor rusești în Italia se găsesc la adresa http://ortodossia.org/chiese-e-parrocchie-2/?lang=it (17.09.2021).

21 Ioan Cozma / Maria Chiara GioRdA, „Per una storia della Chiesa ortodossa romena...", p. 20. 
Acest mozaic ortodox este completat de alte parohii şi misiuni organizate în cadrul episcopiilor ortodoxe pentru Europa Occidentală: 2 parohii bulgare dependente de Episcopia Ortodoxă Bulgară a Europei Occidentale și Centrale (Patriarhia Bulgariei); 22 parohii georgiene dependente de Episcopia Ortodoxă Georgiană a Europei Occidentale (Patriarhia Georgiei), la care se adaugă câteva mici comunități parohiale informale de limbă arabă (siriene și palestiniene) organizate în Roma și Milano și formal subordonate Arhiepiscopiei Ortodoxe Antiohiene a Franței, Europei Occidentale și Meridionale (Patriarhia Antiohiei) ${ }^{22}$. Modificările recente care au urmat reintegrării (sau, pentru opozanți, a ,integrării parțiale”"23) Bisericii Ortodoxe Ucrainene în comuniunea ortodoxă de către Sinodul Patriarhiei Ecumenice (5 ianuarie 2019) permit adăugarea celor 13 parohii ucrainene organizate în Decanatul italo-ucrainean al întregii Italii, Sardiniei și Siciliei, sub jurisdicția Mitropoliei de Paris și a întregii Franțe ${ }^{24}$.

\section{Biserica Ortodoxă Română în Italia}

Comunitatea românească din Italia, chiar dacă nu revendică o prezență foarte veche (comparabilă cu cea grecească), este în momentul de față de departe cea mai compactă și numeroasă dintre toate comunitățile etnice. Conform estimărilor făcute de Institutul Național de Statistică din Italia ${ }^{25}$, comunitatea românească numără 1.145.718 rezidenți (1 ianuarie 2021) dintr-un total de 5.039.637 de rezidenți străini în Italia, adică $22,7 \%$ din totalul de rezidenți străini. $\mathrm{Cu}$ toate că pandemia de Covid19 i-a determinat pe mulți dintre rezidenții vechi să aleagă reîntoarcerea definitivă în România, numărul celor plecați pare să fie substituit, cel puțin în parte, de noi

${ }^{22}$ Davide N. CARnEvale, „I cristianesimi ortodossi in Emilia Romagna...”, p. 82-84.

${ }^{23}$ A se vedea pe această temă Metropolitan of Kykkos and Tylliria NiKIFOROS, The Eccclesial Crisis in Ukraine and its Solution According to the Sacred Canons, Jordanville, New York, Holy Trinity Seminary Press, 2021.

24 Ioan Cozma / Maria Chiara GioRdA, „Per una storia della Chiesa ortodossa romena...", p. 20-21.

${ }^{25}$ A se consulta http://dati.istat.it/Index.aspx?QueryId=19675 (17.09.2021). 
sosiți, fapt ce menține comunitatea românească într-un echilibru numeric constant.

În ceea ce privește numărul ortodocșilor români din Italia, acesta poate fi doar aproximat, deoarece nu există statistici oficiale în acest sens. Episcopia Ortodoxă Română din Italia estimează o comunitate compusă din aproximativ 1.000 .000 de români rezidenţi (adică aproape 65\%) dintr-un total aproximativ de 1.532 .000 de creștini catalogați ca ortodocși. La acest număr trebuie adăugați cetățenii români care lucrează fără acte sau în regim sezonier, fără fie înregistraţi ca rezidenți, precum și numărul destul de semnificativ de cetățeni din Republica Moldova (mulți dintre ei având cetățenia română) care frecventează parohiile românești. $\mathrm{Cu}$ aceste cifre, comunitatea ortodoxă românească ocupă locul al treilea în calitate de comunitate confesională în Italia, după cea musulmană, care numără 1.764 .000 de rezidenți $(33,2 \% \text { din numărul total de străini })^{26}$, și primul loc în rândul comunităților ortodoxe.

O primă mențiune despre o încercare de organizare a unei parohii ortodoxe românești în Italia găsim într-un act al cancelariei patriarhale, datat 10 decembrie 1941, prin care patriarhul Nicodim Munteanu îl numea pe preotul Gheorghe Țilea pe postul de preot paroh al comunității din Roma ${ }^{27}$. Probabil din cauza războiului, preotul Țilea nu s-a prezentat niciodată la noua sa parohie în Roma, iar după război, instaurarea regimului comunist în România a făcut de-a dreptul imposibil orice demers al Patriarhiei de purtare de grijă sau organizare a vreunei parohii în Italia. O altă tentativă de organizare a românilor ortodocși din peninsulă într-o parohie a fost făcută de către mitropolitul român Visarion Puiu (refugiat politic). Acesta a locuit la mănăstirea catolică de la Maguzzano, lângă Verona, în perioada decembrie 1945 - noiembrie 1947, timp în care a desfăşurat o bogată activitate pastorală și misionară fără să reușească, însă, să înființeze vreo parohie ${ }^{28}$.

${ }^{26}$ IDOS, Dossier Statistico Immigrazione 2020, p. 231.

27 Ioan Cozma / Maria Chiara GioRdA, „Per una storia della Chiesa ortodossa romena...", p. 27.

${ }^{28}$ Ibidem, p. 27-28. 
Timp de aproape 30 de ani, nevoile spirituale ale micii comunități ortodoxe românești împrăștiate în principal în marile orașe (Roma, Milano, Torino, Florența) și formată în mare parte din refugiaţi politic sau ca urmare a căsătoriilor mixte, au fost suplinite sporadic de preoții români din Franța sau Elveția care aparțineau de diverse jurisdicții (unele necanonice). Odată cu primirea Episcopiei Europei Occidentale cu sediul la Paris (înființată de către mitropolitul Visarion Puiu în anul 1950) în Patriarhia Română în anul 1972 (ridicată la rangul de arhiepiscopie în anul 1974 și la rangul de mitropolie în anul 2001), credincioșii din Italia au intrat sub jurisdicția acestei episcopii.

Prima parohie pe teritoriul Italiei a luat ființă în anul 1975 la Milano și a primit hramul „Pogorârea Duhului Sfânt”. Un rol fundamental la înființarea parohiei l-a avut preotul Traian Valdman, aflat în Italia din anul 1974 cu o bursă de studii la Universitatea Catolică din Milano, ca urmare a relațiilor ecumenice dintre Patriarhia Română și Biserica Romano-Catolică. Circumstanțe similare vor determina în anul 1979 înființarea celei de-a doua parohii, la Torino, având hramul „Cuvioasa Parascheva” şi fiind încredințată păstoririi preotului Gheorghe Vasilescu, bursier trimis de către Patriarhia Română la Universitatea catolică din Milano. În anul 1983, a fost înființată parohia din Bari („Sfânta Treime și Sf. Nicolae") prin contribuția preotului Mihai Driga, aflat la studii doctorale la Institutul Ecumenic San Nicola din Bari. Eforturile misionare ale părintelui Traian Valdman au dus la înființarea, în anul 1984, a celei de-a patra parohii la Florența, având hramul „Înălțarea Domnului”, fiind numit în postul de preot paroh părintele Petre Coman din București ${ }^{29}$.

După căderea comunismului, numărul românilor ortodocși a crescut semnificativ în peninsulă fapt ce a dus în mod evident la înmulțirea treptată a parohiilor. La data instalării Preasfințitului Siluan S,pan la Roma (8 mai 2008) ca episcop titular al Episcopiei Ortodoxe Române din Italia, numărul total al parohiilor ajunsese la

29 Ibidem, p. 30-33. O istorie detaliată a acestor parohii se găsește și în volumul Almanah bisericesc, Roma, Episcopia Ortodoxă Română a Italiei, 2016. 
74, iar în anii care au urmat numărul lor s-a înmulțit, fiind însoțite și de înființarea unor mănăstiri și centre sociale. Potrivit raportului Adunării eparhiale din data de 16 februarie 2021, episcopia numără în prezent 290 de parohii (286 de preoți și 13 diaconi), 132 de misiuni (filii), 5 mănăstiri, 2 schituri, 6 capele eparhiale (paraclise) și 3 centre pastorale organizate în 24 de protopopiate ${ }^{30}$. Aceste cifre sunt de-a dreptul impresionante dacă luăm în calcul istoria scurtă a prezenței ortodoxe românești în Italia. În spațiul public italian, această realitate este foarte bine reflectată prin diversitatea spațiilor de cult: biserici, săli, amfiteatre, spații improvizate, construcții noi, etc. O contribuție importantă în organizarea și funcționarea multor parohii a avut-o și în continuare încă o are Biserica RomanoCatolică: aproape $80 \%$ din parohii folosesc drept lăcașuri de cult biserici și clădiri catolice.

\section{Strategii și dinamici în crearea și folosirea locaşurilor de cult}

Numărul mare de credincioși și locuri de cult situează episcopia românească din Italia printre cele mai active și prolifice minorități religioase din spațiul italian. Acest lucru, fără îndoială, se datorează viziunii pastoral-misionare a episcopului Siluan și a arhiereului-vicar Atanasie Rusnac, a căror obiectiv a fost încă de la început acela de a face cât mai vizibilă (spiritual şi material) prezența ortodoxă românească în peninsulă. $\mathrm{Cu}$ toate acestea, episcopia nu beneficiază până în prezent de o recunoaştere din partea statului italian ${ }^{31}$ care să îi permită să se bucure de toate drepturile la fel cu, de exemplu, arhiepiscopia greacă sau alte 11

${ }^{30}$ Episcopia Ortodoxă Română a Italiei, Comunicat de presă nr. 2/16 februarie 2021, disponibil la https://www.episcopia-italiei.it/index.php/ro/comunicate/8160comunicat-de-presa-nr-2-din-2021 (18.09.2021).

31 Articolul 8 din Constituția Italiei prevede posibilitatea încheierii de acorduri (Intese) cu cultele acceptate pe teritoriul Italiei. A se vedea Maria Chiara GIORDA / Alberto VANOLO, „Religious diversity and inter-faith competition: the politics of camouflage in Italian cities", în Territory, Politics, Governance, 5 (2019), p. 222-240. 
confesiuni religioase cărora, în ciuda faptului că sunt net inferioare ca număr de credincioși și unități de cult, statul italian le-a acordat acest drept prin încheierea de acorduri (intese) ${ }^{32}$.

Statutul juridic al episcopiei românești este doar acela de „cult permis de către Stat” (culto ammesso), recunoscut în baza Decretului prezidențial din 12 septembrie 2011. Această recunoaștere legală a permis episcopiei să înființeze parohii, mănăstiri și centre pastorale pe teritoriul Italiei. În baza articolul 4 din Statutul episcopiei ${ }^{33}$, acestea sunt recunoscute ca unităţi componente ale episcopiei şi au dreptul să fie înregistrate la Agenția de Venituri (Agenzia delle Entrate) cu cod fiscal propriu, fără însă să beneficieze de personalitate juridică ca un cult recunoscut.

Trebuie subliniat faptul că deși dețin cod fiscal, multe parohii au întâmpinat greutăți în a avea un locaș de cult. În multe cazuri, pentru a închiria un locaș de cult, altul decât catolic, unele parohii aflate la începuturile existenței lor au fost nevoite să recurgă la diverse artificii juridice. Spre exemplu, un astfel de artificiu a fost trecerea ca titular pe contractul de încheiere a Asociaţiei „San Lorenzo dei romeni”, care este o asociație caritabilă a episcopiei (înregistrată ca ONLUS, adică organizație non-profit de utilitate socială) axată îndeosebi pe serviciile de asistență socială, educație și formare spirituală ${ }^{34}$.

Înființarea și funcționarea parohiilor ortodoxe românești este în principal caracterizată de trecerea prin mai multe faze: de la statutul de oaspete al parohiilor sau diverselor instituții catolice care au pus la dispoziția comunităților românești biserici, săli sociale și

32 A se vedea Federica BotтI, ,Sui contenuti di una possibile Intesa con la Chiesa Ortodossa Romena in Italia", în Stato, Chiese e pluralismo confessionale (Rivista telematica), 2008, https://www.statoechiese.it/images/uploads/articoli_pdf /botti_sui_contenuti.pdf?pdf=sui-contenuti-di-una-possibile-intesa-con-la-chiesaortodossa-romena-in-ita (18.09.2021).

33 A se vedea Statutul pentru organizarea și funcționarea Episcopiei Ortodoxe Române a Italiei la adresa https://episcopia-italiei.it/media/statut_eori.pdf (19.09.2021).

34 Informații suplimentare se găsesc la adresa https://www.sanlorenzodeiromeni.it (19.09.2021). 
culturale la cel de posesor al unei biserici sau clădiri seculare (închiriate sau în contract de comodat) și, în final, la cel de proprietar al lăcașurilor de cult și, după caz, a altor anexe parohiale (prin cumpărare sau construire ex-novo). Într-o terminologie specifică geografiei religiilor, se poate vorbi de o trecere de la faza de seek place (căutare a unui spațiu de cult adecvat), la cea de keep place (posesia temporară a unui spațiu și convertirea lui în spațiu de cult ortodox) și, în fine, la cea de make place (construirea propriului locaș de cult sau cumpărarea unui spatiu secular și transformarea lui în locaş de cult ortodox). În fiecare din aceste faze se pot observa diverse dinamici de folosire a spațiilor de cult.

O primă dinamică este partajarea sau condiviziunea sincronică temporară, prin care un spațiu este transformat sau „convertit” temporar într-un spaţiu liturgic ortodox (spațiul este amenajat cu masă de slujire, icoane, iconostas mobil, pangar, suporturi de lumânări, strane, tetrapoduri etc), iar la terminarea slujbelor este desființat sau dezasamblat total sau parțial, în funcție de necesităţile liturgice ale parohiei sau, după caz, ale comunităţilor religioase care folosesc respectivul spațiu în mod alternativ sau partajat.

Cea de-a doua dinamică este partajarea sau condiviziunea diacronică, în care spațiile folosite temporar devin treptat locuri permanente; este vorba de acele locașuri de cult care aparțin Bisericii Romano-Catolice, a primăriilor sau a diverselor fundații și asociații, dar care nu mai sunt în uz (au fost de-consacrate) sau de acele spațiile seculare (foste spații comerciale, depozite, ateliere etc.), aflate în proprietate publică sau privată, care sunt transformate de comunitățile parohiale românești în lăcașuri de cult ortodoxe. În foarte multe cazuri, această dinamică de substituire a făcut trecerea de la statutul provizoriu/temporar al parohiei la cel definitiv, proces finalizat, de obicei, prin cumpărarea clădirii respective ${ }^{35}$. Substituirea unui spațiu ex-religios catolic sau al unui spațiu secular cu un loc de cult ortodox creează o hibridizare a memoriei spațiului foarte complexă care este legată de dimensiunea simbolică, socială, religioasă și politică a locului.

${ }^{35}$ Ioan COZMA / Maria Chiara GIORDA, ,Sostituire, condividere, costruire...”, p. 29. 
Construirea ex-novo (sau ridicarea de la zero) a unui locaș de cult este o altă dinamică verificată în procesul de consolidare a parohiilor ortodoxe românești în peninsula italiană. Dinamicile spațiale sunt utile pentru a investiga care este relaţia locului $\mathrm{cu}$ spațiul înconjurător (urban sau rural) și traiectoriile pe care fiecare loc în parte le generează. Această perspectivă spaţială are în vedere un alt punct de observație, și anume cel al raporturilor sociale și politice ale instituţiilor statele italiene $\mathrm{cu}$ grupurile religioase minoritare, precum și al raporturilor care intersectează diversele jurisdicții ortodoxe cu Biserica catolică majoritară, pentru a înțelege dacă/cum spațiile religioase - în mod special cele condivize creează strategii și dinamici de competiţie, toleranţă, solidaritate sau/și conflict ${ }^{36}$.

Într-un studiu publicat recent subliniam faptul că spaţiile religioase partajate (condivize) sunt acele locuri care sunt folosite sau, după caz, revendicate de două sau mai multe confesiuni religioase, sau care au fost convertite pentru uz de la o religie/confesiune la alta, printr-o strategie pe care noi tehnic am numit-o bottom-up (de jos în sus), spre deosebire de locurile construite/finanțate sau proiectate de instituții civile sau militare (capele, biserici militare sau spitalicești) în care se folosește strategia top-down (de sus în jos) și care, în unele cazuri, au o valoare mai mult simbolică decât o utilitate concretă (aici intră, de exemplu, capelele multireligioase din spitale sau aeroporturi) ${ }^{37}$.

În crearea și folosirea spaților de cult pentru parohiile românești din Italia se pot identifica următoarele strategii: top-top, care se referă la faptul că folosirea sau crearea unui spațiu de cult pentru comunitatea românească este rezultatul acordurilor dintre ierarhii ortodocși si ierarhii catolici, dintre ierarhii ortodocși și autoritățile civile locale sau guvernamentale, sau dintre autoritățile

${ }^{36}$ Cât privește competiția pe care o creează locurile religioase condivize, a se vedea Robert M. HAYDEN, ,Antagonistic tolerance: Competitive Sharing of Religious Sites in South Asia and the Balkans", în Current Anthropology, 42: 2 (2002), p. 205-231; IDEM, Antagonistic Tolerance: Competitive Sharing of Religious Sites and Space, London / New York, Routledge, 2016.

${ }^{37}$ Ioan CozMA / Maria Chiara GIORDA, „Sostituire, condividere, costruire...”, p. 27. 
civile italiene și române; top-down, se referă la acele cazuri în care finanțarea cumpărării sau a construirii unui locaș de cult s-a făcut $\mathrm{cu}$ contribuția autorităților statelor românești; middle-middle, crearea sau folosirea unui loc s-a făcut prin înţelegerea scrisă/contractuală sau verbală dintre parohul român și parohul sau responsabilul lăcașului de cult catolic; middle-up, în care obținerea unui locaș de cult a fost rezultatul acordurilor încheiate de către preotul paroh român și autoritățile superioare bisericești catolice (episcopul sau vicarul diocezan) sau cu autoritățile civile (primarul, administrația locală) sau responsabilii asociațiilor și fundațiilor care dețin locașurile de cult; bottom-up, când construirea sau amenajarea unui locaş de cult s-a făcut prin iniţiativa și contribuţia credincioșilor.

Așa cum deja am amintit puțin mai devreme, dinamica creării și funcționării spațiilor de cult ortodoxe românești din Italia include acel tip de substituție prin care un loc de cult catolic este convertit într-un loc de cult ortodox. Un rol foarte important în acest proces de ,hibridizare a spațiului" 38 l-a avut în mare parte Biserica Romano-Catolică, prin faptul că a acceptat ca o parte din lăcașurile sale de cult nefolosite sau folosite ocazional să fie date spre folosință parohiilor românești. Bisericile catolice au fost încă dintru început preferate de către comunitățile parohiale ortodoxe în primul rând datorită faptului că pot să fie cu ușurință ,convertite” în spaţii de cult ortodoxe. Trebuie subliniat faptul că nu toate locaşurile de cult din Italia sunt în proprietatea Bisericii Catolice; unele biserici se găsesc în proprietatea primăriilor ori în proprietatea unor instituții sau fundații culturale ori religioase. Numărul mare de locașuri de cult catolice închise sau parțial folosite se datorează în primul rând schimbărilor normative și administrative care au obligat Biserica Romano-Catolică să-și restructureze parohiile și să redefinească jurisdicțiile: este vorba de Legea nr. 847/29 Septembrie 1964 și de Decretul Ministerial nr. 1444/1968 care

38 Maria Chiara GiORDA / Andrea LONGHI, „Religioni e spazi ibridi nella città contemporanea: profili di metodo e di storiografia", în Atti e Rassegna Tecnica della Società degli Ingegneri e degli Architetti in Torino, 152: 73/2 (2019), p. 113. 
prevăd ca la un locaș de cult să fie arondat un număr cuprins între 5.000 și 10.000 locuitori $^{39}$.

Potrivit datelor furnizate de Episcopia Ortodoxă Română din Italia, 350 de lăcașuri de cult dintr-un total de 437 folosesc locașuri de cult catolice fie în baza unui contract de comodat sau de închiriere, fie în baza unui acord verbal ${ }^{40}$. Un prim exemplu, în aceste sens, este cel al Parohiei „Pogorârea Duhului Sfânt” din Milano, care de la înființarea ei în anul 1975 și până în anul 1996, a folosit biserica catolică San Benedetto alle Monache situată pe strada Giorgio Giulini, în baza unui contract de închiriere, iar din anul 1996 și până prezent, parohia folosește în mod exclusiv biserica catolică Santa Maria della Vittoria de pe strada Edmondo De Amicis nr. 13, în baza unui contract de comodat. Stipulările contractuale au permis parohiei să transforme interiorul bisericii într-un spațiu de cult ortodox, cu masă de altar, iconostas sculptat din lemn masiv, icoane, strane, tetrapoduri, suporturi de lumânări etc. ${ }^{41}$. Un alt exemplu este cel al Parohiei „Înălțarea Sfintei Cruci” din Torino, care folosește spre slujire încă de la înființare (2001) fosta biserică catolică Santa Croce de pe strada Via Accademia Albertina nr. 11. Biserica deși în proprietatea primăriei, se află în administrarea Arhiepiscopiei catolice din Torino, cea care, de fapt, a intermediat concesionarea bisericii și a spațiilor adiacente parohiei românești tocmai pentru a menține calitatea de locaș de cult a spațiului (în proiectul primăriei, clădirea urma să fie transformată în bibliotecă $)^{42}$. Biserica a fost sfinţită în data 13 octombrie 2001 de către arhiepiscopul Iosif al Mitropoliei Ortodoxe Române de Europa Occidentală şi Meridională ${ }^{43}$, fiind dotată conform standardelor liturgice și canonice ortodoxe (masă de altar, iconostas sculptat din lemn masiv, tetrapoduri, icoane și strane, suporturi de lumânări etc.).

39 Maria Chiara Giorda / Alberto VANOLO, „Religious diversity and inter-faith competition...”, p. 226.

${ }^{40}$ Ioan COZMA / Maria Chiara GIORDA, ,Sostituire, condividere, costruire...”, p. 27.

${ }^{41}$ IDEM, „Per una storia della Chiesa ortodossa romena...”, p. 29-30.

42 Alessandro GrANERO, „Parrocchia ortodossa romena dell'Esaltazione della Santa Croce", în Quaderni di Benvenuti in Italia, 13 (2018), p. 100-101.

${ }^{43}$ Almanah bisericesc, p. 221. 
O altă categorie de substituție se referă la acele spații seculare convertite în locașuri de cult ortodoxe. Alegerea spațiilor seculare a fost determinată fie din lipsa unor locașuri de cult disponibile în anumite zone, fie din cauza refuzului unor episcopi catolici de a oferi locașuri de cult parohiilor ortodoxe, chiar dacă această posibilitate exista. În unele cazuri, refuzul părții catolice de a oferi locașuri de cult ortodocșilor a fost motivat prin aceea că în România, credincioșilor greco-catolici le-a fost refuzată restituirea bisericilor confiscate sau intrate în proprietatea parohiilor ortodoxe române în perioada regimului comunist. În alte cazuri, nu a existat un refuz direct din partea autorităților catolice, însă condițiile impuse privind folosirea locașului de cult nu puteau să fie îndeplinite fie în parte, fie în totalitate de către parohiile românești. Trebuie să menționăm că au existat și cazuri în care unii preoți români mai fundamentaliști au refuzat să accepte să slujească în biserici catolice pe motiv că sfintele canoane interzic săvârșirea liturghiei sau a oricărei rugăciuni în locaşuri de cult eretice, preferând, astfel, în schimb, spațiile seculare ${ }^{44}$. Tot în această categorie intră și cazul acelor parohii care au funcționat la început în biserici catolice dezafectate și apoi au achiziționat clădiri laice care au fost transformate în lăcașuri de cult.

Conform informațiilor primite din partea Episcopiei Ortodoxe Române din Italia, 45 de parohii au convertit spații seculare (săli de adunare sau de teatru, foste hale comerciale, și chiar foste baruri sau restaurante etc.) în locașuri de cult, folosind clădirile respective în baza unui contract de închiriere; 37 de parohii au cumpărat foste biserici catolice de-consacrate sau spații seculare (foste magazii, ateliere auto, clădiri private, foste localuri publice) pe care le-au transformat în biserici ortodoxe ${ }^{45}$. Se constată în ultimii ani o preferință tot mai mare a parohiilor pentru achiziționarea de spații seculare care să fie transformate apoi în locașuri de cult.

În această categorie de substituție de la secular la religios intră, de exemplu, sediul Episcopiei Ortodoxe Române din Italia,

${ }^{44}$ Ioan COZMA / Maria Chiara GIORDA, ,Sostituire, condividere, costruire...”, p. 28.

${ }^{45}$ Episcopia Ortodoxă Română a Italiei, Comunicat de presă nr. 2/16 februarie 2021. 
situat la periferia Romei pe Via Ardeatina nr. 1741. Sediul episcopiei, la origine o vilă construită în anii '50, a fost achiziționat în vara anului 2008, cu sprijinul Patriarhiei Române și cu contribuția financiară a statului român. De la inaugurarea sa și până în prezent, a trecut printr-un proces amplu de sistematizare şi adaptare a spațiilor pentru a putea răspunde atât nevoilor administrative ale episcopiei, cât și nevoilor mănăstirii de maici (înființată în anul 2008) care își are sediul în incinta episcopiei. Într-un depozit dezafectat, aflat lângă clădirea principală, a fost amenajată o capelă mică cu hramul „Adormirea Maicii Domnului”, care servește ca loc de rugăciune și slujire pentru cei doi ierarhi și comunitatea monastică din incinta episcopiei. Printre proiectele episcopiei se află și cel de construire în incinta respectivă a unei catedrale din lemn ${ }^{46}$.

În dinamica de condiviziune sincronică a spaţiului intră şi coexistența, adică folosirea aceluiași loc (locaș de cult, social sau cultural) de către două comunități religioase. În existența multor parohii ortodoxe românești din Italia, coexistența a fost o dinamică de trecere spre substituţie sau spre autonomia integrală în gestionarea unui propriu locaș de cult. În această categorie intră acele cazuri când parohiilor românești li s-au oferit spre slujire altarul principal sau un altar lateral, sau chiar o capelă adiacentă dintr-o biserică catolică sau dintr-o biserică protestantă, evident cu respectarea strictă a unor orare de slujire care să nu perturbe sau să se suprapună peste slujbele instituţiei gazde. Acesta a fost cazul, spre exemplu, al Parohiei „Cuvioasa Parascheva” din Torino, care între anii 1978 și 1981 a împărțit același spațiu de cult cu Parohia Greco-Catolică Italo-Albaneză San Michelle din Torino, săvârșind duminica liturghia după terminarea liturghiei parohiei gazdă ${ }^{47}$. Un caz de coexistență prin partiţionarea locului a fost cel al parohiei „Sfânta Treime și Sfântul Nicolae” din Bari, care de la înființare (1983) şi până în anul 2007 a săvârşit sfintele slujbe în „Capela

46 Ioan Cozma / Maria Chiara GioRdA, „Per una storia della Chiesa ortodossa romena...”, p. 47-48; IDEM, „Residenze vescovili nei monasteri: una lunga storia nell'ortodossia romena", în Diritto e Religioni, 13: 1 (2019), p. 326-334.

${ }^{47}$ Almanah bisericesc, p. 217-218. 
Orientală" a bazilicii San Nicola, aceasta fiind dotată de părinții dominicani cu tot ceea a fost necesar pentru un locaș de cult ortodox (iconostas, icoane, tetrapoduri etc.) ${ }^{48}$.

Tot în categoria de coexistență intră și cazurile de folosire a unui spațiu religios prin suprapunere: este vorba de acele parohii românești care încă mai folosesc pe post de locaș de cult spații (săli de reuniuni, amfiteatre, săli de sport) situate la subsolul unor biserici catolice. Conform datelor parvenite de la episcopie, în această categorie intră astăzi un număr aproximativ 16 parohii românești.

În cele mai multe cazuri, parohiile folosesc altare și iconostase mobile, ușor de asamblat și dezasamblat la terminarea slujbelor. În acest caz, chiar dacă programul liturgic al celor două parohii se suprapune, în mod deosebit duminica, acest lucru nu afectează desfãșurarea firească a slujbelor. Unele contracte de comodat sau închiriere prevăd folosirea alternativă a spațiului în caz de nevoie şi de către partea catolică. De comun acord cu partea ortodoxă, aceste activități sunt programate în zile și ore care să nu perturbe programul slujbelor și activitățile părții ortodoxe. Dacă acest lucru totuși se întâmplă, partea catolică oferă ca alternativă părții ortodoxe alt spațiu. Acesta este cazul, spre exemplu, al Parohiei „Nașterea Maicii Domnului” din Roma, care folosește spre slujire din anul 2001 amfiteatrul Bisericii Romano-Catolice Natività di Nostro Signore Gesù Cristo, situată pe Via Galia nr. 162, dar și cazul Parohiei „Înălțarea Sfintei Cruci” din Roma, care folosește din anul 2005 ca locaș de cult sala de activități sociale și recreative situată la subsolul Mănăstirii Suore delle Assunzione, de pe Via Alessandro Viviani nr. $24^{49}$. În acest ultim caz, contractul prevede ca în situaţia în care mănăstirea are nevoie să folosească spaţiul concesionat părții ortodoxe în zilele de duminică, parohiei românești îi este oferită la schimb spre slujire biserica mare.

48 Ibidem, p. 499; Ioan Cozma / Maria Chiara GiordA, „Sostituire, condividere, costruire...”, p. 29.

49 Almanah bisericesc, p. 35; Maria Chiara GIORDA / Andrea LONGHI, „Religioni e spazi ibridi nella città contemporanea...”, p. 112; Ioan CozMA / Maria Chiara GIORDA, „Sostituire, condividere, costruire...”, p. 29. 
Așa cum am amintit deja, lipsa unui acord (intesa) cu statul italian creează o situație destul de delicată pentru parohii, cu consecințe nu doar asupra statutului juridic și a capacității de a achiziționa sau construi propriile locașuri de cult, dar și asupra statutului personalului clerical care deservește aceste parohii. În unele cazuri, parohiile sunt înregistrate ca unități de cult (ente di culto) fără personalitate juridică, iar băncile refuză să ofere credite pentru cumpărarea, modernizarea sau renovarea vreunui imobil pe motiv că statutul lor ambiguu nu prezintă o garanție suficientă în acest sens. În multe cazuri, preoții împreună cu credincioşii au fost nevoiți să facă împrumuturi bancare personale (cu garanți) pentru a cumpăra un locaş de cult. În unele cazuri, împrumuturile bancare au fost făcute direct de Episcopie, care în calitatea sa de cult permis de către statul italian are capacitatea juridică de a împrumuta sau de a garanta împrumuturile făcute de către unitățile sale de cult, respectiv parohiile și mănăstirile din Italia.

Trebuie subliniat faptul că, în momentul de față, în Italia nu există o uniformitate legislativă în ceea ce privește autorizarea și construirea spațiilor de cult. Actele normative din anii '60 care condiționează numărul de biserici de numărul de locuitori aveau în vedere cu precădere cultul catolic. Prin urmare, gestionarea achiziționării, convertirii sau construirii unui locaş de cult, altul decât cel catolic, este de multe ori lăsată în sarcina administrațiilor locale, regionale sau urbane care acționează în mod discreționar ${ }^{50}$. În mare parte din cazuri, locaşurile de cult ortodoxe create prin lucrările de restaurare și remodelare a unor clădiri seculare nu sunt înregistrate în actele oficiale civile ca biserici sau locuri de cult. De exemplu, în contractul de închiriere al imobilului care a fost convertit în locaş de cult de către Parohia „Sfântul Mucenic Ipatie” din Civita Castelana (provincia Viterbo) este menționat doar faptul că ,imobilul este închiriat parohiei pentru a fi folosit în conformitate cu acordul stabilit între părțile contractante",51.

\footnotetext{
${ }^{50}$ A se vedea Natascia MARCHEI, Il „,Diritto al tempio”. Dai vincoli urbanistici alla prevenzione securitaria, Napoli, Editoriale Scientifica, 2018.

${ }^{51}$ Ioan CozMA / Maria Chiara GIORDA, „Sostituire, condividere, costruire...”, p. 30.
} 
În ciuda lacunelor legislative și a incoerenței la nivelul administrațiilor locale, se constată în ultimii ani o încercare susținută a parohiilor de a-și construi propriile locașuri de cult. Din informațiile pe care le avem de la episcopie, au fost definitivate până în momentul de față 9 biserici parohiale (Abano Terme, Brescia 1, Chivasso, Guidonia, Moncalieri, Ostia, Rieti, Verona și Venezia Mestre), în timp ce alte 2 parohii (Limen și Orbassano) au locașurile de cult în faze terminale de construcție; la acestea se adaugă 6 terenuri, achiziționate de parohii prin diferite modalități (concesiune, vânzare și cumpărare), pe care este prevăzută construirea de locaşuri de cult și centre sociale ${ }^{52}$. O mare parte din bisericile noi au fost construite pe terenuri concesionate parohiilor de către administrațiile locale pe o perioadă lungă de timp (99 de ani), în schimb, unele parohii au fost nevoite să achiziționeze terenul de construcție. În unele situații, pentru intra în posesia terenului, s-a apelat la diverse artificii juridice, cum este, de exemplu, cazul Parohiei „Sfântul Ilie și Sfântul Zenon" din Verona. Terenul pe care este construită biserica și centrul social (cca. $5100 \mathrm{mp}$, Via Palladio nr. 21-27) a fost cumpărat de statul român la data de 5 aprilie 2012 de la primăria din Verona și ulterior donat Episcopiei Ortodoxe Române din Italia, care, la rândul ei, 1-a transferat parohiei din Verona; cheltuielile privind cumpărarea terenului au fost, în mare parte, suportate de parohie ${ }^{53}$.

Se constată, de asemenea, lipsa de uniformitate în ceea ce privește stilul arhitectural al bisericilor noi: 2 biserici sunt construite din lemn în stilul tradițional maramureșean (Biserica „Sfinții 40 de Mucenici din Sevastia” din Montcalieri și Biserica „Sfântul Ierarh Iosif de Nou de la Partoș” din Rieti), la acestea se adaugă o a treia biserică din lemn, în stilul transilvănean (Biserica „Maica Domnului Prodromița” din Abano Terme/Padova); celelalte sunt construite din zid și combină diverse stiluri arhitecturale.

52 Episcopia Ortodoxă Română a Italiei, Comunicat de presă, 2021; PS Atanasie Rusnac, arhiereu-vicar, Interviu, 19.05.2021.

${ }^{53}$ Ioan CozMA / Maria Chiara GIORDA, ,Sostituire, condividere, costruire...”, p. 30. 


\section{Concluzii}

În istoria nu tocmai scurtă a prezenței ortodoxe românești în Italia se poate observa un proces de tranziţie de la un statut temporar şi incert de confesiune-oaspete, alcătuită exclusiv din emigranţi, la un statut de Biserică stabilă, integrată teritorial, cultural şi social. Se poate observa cum de la o dinamică de seek place (căutare de spațiu), fluidă și temporară (vizibilă în dinamici de substituire și coexistență), s-a trecut în ultimii ani la o dinamică de make place (construire a propriului spațiu), care se reflectă în primele încercări, unele încă nefinalizate, de a construi biserici ortodoxe românești vizibile și recunoscute formal. Spontaneitatea care a marcat începuturile primelor parohii, odată cu înființarea episcopiei românești în anul 2007, a fost însoțită și apoi aproape în totalitate substituită de o strategie națională marcată de un dinamism permanent, care are ca obiectiv înființarea continuă de parohii peste tot unde există o comunitate de români ortodocși.

În mod evident, spre deosebire de religiile necreștine, legăturile istorice și bisericești între Biserica Ortodoxă și Biserica Romano-Catolică au contribuit la acest proces de acceptare și integrare, atât la nivel social, cât și la nivel religios a comunităților ortodoxe românești. Din păcate, însă, această recunoaștere și integrare în spațiul religios italian nu se reflectă (încă) și la nivel politic, prin recunoașterea Episcopiei și a unităţilor sale administrative ca unități de cult cu personalitate juridică, care să le permită să se bucure de drepturi depline la fel ca cele 12 confesiuni minoritare care beneficiază deja de aceste drepturi.

$\cos 80$

\section{Bibliografie}

1. ADESSI, Elena / DEL Bove, Alberto, L'impatto della pandemia sui beneficiari di accoglienza del Lazio meridionale, în Ginevra Demaio (ed.), Osservatorio sulle Migrazioni a Roma e nel Lazio. 
Sedicesimo Rapporto, Roma, Centro Studi e Ricerche IDOS, 2021, p. 52-56.

2. Almanah bisericesc, Roma, Episcopia Ortodoxă Română a Italiei, 2016.

3. AlZATI, Cesare, „L'Ortodossia nello spazio romeno e il significato della sua presenza in Italia per la Comunione tra le Chiese", în Gino Battaglia (ed.), L'Ortodossia in Italia: le sfide di un incontro, Bologna, Edizioni Dehoniane, 2011, p. 171-198.

4. Assemblea legislativa Regione Emilia-Romagna (ed.), I monoteismi in Emilia-Romagna: Ebraismo, Cristianesimo ortodosso, Islam, Bologna, 2017.

5. Ballabio, Fabbio / SAVARAnI, Brunetto (eds.), Religioni in Italia: Il Nuovo Pluralismo Religioso, Bologna, Editrice Missionaria Italiana, 2011.

6. BATTAGLIA, Gino, „Introduzione. La tradizione bizantina in Italia, tra fede e storia", în Gino Battaglia (ed.), L'Ortodossia in Italia: le sfide di un incontro, Bologna, Edizioni Dehoniane, 2011, p. 1-29.

7. Berzano, Luigi / CASSINASCO, Andrea, Cristiani d'Oriente in Piemonte, Torino, L'Harmattan, 1999.

8. BIRTACHAS, Efstathios, „Un secondo” vescovo a Venezia: il metropolita di Filadelfia (secoli XVI-XVIII)", în Maria F. Tiepolo / Eurigio Tonetti (eds.), I Greci a Venezia, Veneția, Istituto Veneto di Scienze Lettere ed Arti, 2002, p. 103-122.

9. BotTI, Federica, „Sui contenuti di una possibile Intesa con la Chiesa Ortodossa Romena in Italia", în Stato, Chiese $e$ pluralismo confessionale (Rivista telematica), 2008, disponibil la https://www.statoechiese.it/images/uploads/articoli_pdf/botti_sui _contenuti.pdf?pdf=sui-contenuti-di-una-possibile-intesa-con-lachiesa-ortodossa-romena-in-ita (18.09.2021).

10. BROUSCARI, Ersi, „La chiesa di San Giorgio dei Greci a Venezia e l'architettura", în Maria F. Tiepolo / Eurigio Tonetti (eds.), I Greci a Venezia, Veneția, Istituto Veneto di Scienze Lettere ed Arti, 2002, p. 533-555.

11. CALABI, Donatella, „L'insediamento greco e il contesto urbano”, în Maria F. Tiepolo / Eurigio Tonetti (eds.), I Greci a Venezia, Veneția, Istituto Veneto di Scienze Lettere ed Arti, 2002, p. 555-568.

12. CARneVale, Davide N. / GîRnEȚĂ, Simona F., Aspettative $e$ bisogni delle comunità religiose a Bologna - Le chiese ortodosse, Bologna, Comune di Bologna - AMITIE code, 2018. 
13. IDEM, Comunità Da Remoto. „Il Laboratorio Della Diaspora Cristiano-Ortodossa Davanti Alla Pandemia", în Comparative Cultural Studies - European and Latin American Perspectives, 6: 13 (2021), p. 143-164.

14. Carnevale, Davide N., „I cristianesimi ortodossi in EmiliaRomagna: una mappatura", în Assemblea legislativa Regione Emilia-Romagna (ed.), I monoteismi in Emilia-Romagna: Ebraismo, Cristianesimo ortodosso, Islam, Bologna, 2017, p. 75-121.

15. Centro Studi e Ricerche IDOS și Centro Studi CONFRONTI (eds.), Dossier Statistico Immigrazione 2020, Roma, Centro Studi e ricerche IDOS, 2020.

16. Cingolani, Pietro, Romeni d'Italia, Bologna, Mulino, 2009.

17. CozMA, Ioan / GIORDA, Maria Chiara, „Per una storia della Chiesa ortodossa romena in Italia", în Quaderni di Benvenuti in Italia, 13, 2018, p. 19.

18. IDEM, „Residenze vescovili nei monasteri: una lunga storia nell'ortodossia romena", în Diritto e Religioni, 13: 1 (2019), p. 326-334.

19. Episcopia Ortodoxă Română a Italiei, Comunicat de presă $n r$. 2/16 februarie 2021, disponibil la https://www.episcopiaitaliei.it/index.php/ro/comunicate/8160-comunicat-de-presa-nr-2din-2021 (18.09.2021).

20. FedAlto, Giorgio, „La Comunità greca, La Chiesa di Venezia, La Chiesa di Roma", în Maria F. Tiepolo / Eurigio Tonetti (eds.), I Greci a Venezia, Veneția, Istituto Veneto di Scienze Lettere ed Arti, 2002, p. 83-102.

21. GIORDA, Maria Chiara / CozMA, Ioan (eds.), „Luoghi di culto della Chiesa ortodossa romena in Italia: dinamiche di insediamento" (în curs de publicare).

22. IDEM, „Sostituire, condividere, costruire: le parrocchie ortodosse romene nel tortuoso cammino verso il riconoscimento", în Religione e Società, 35: 96 (2020), p. 23-32.

23. IDEM, Ortodossi romeni d'Italia, în Quaderni di Benvenuti in Italia, 13 (2018).

24. GIORDA, Maria Chiara / LONGHI, Andrea, „Religioni e spazi ibridi nella città contemporanea: profili di metodo e di storiografia", în Atti e Rassegna Tecnica della Società degli Ingegneri e degli Architetti in Torino, 152: 73/2 (2019). 
25. GIORDA, Maria Chiara / VANOLO, Alberto, „Religious diversity and inter-faith competition: the politics of camouflage in Italian cities", în Territory, Politics, Governance, 5 (2019), p. 222-240.

26. GIORDAN, Giuseppe / GugliELmI, Marco, „Be fruitful and multiply... Fast! The Spread of Orthodox Churches in Italy", în Jörg Stolz / Christophe Monnot (eds.), Congregations in Europe, Cham, Springer, 2018, p. 53-69.

27. GIORDAN, Giuseppe, „A world in motion: The plurality of orthodox churches in Italy", în Giuseppe Giordan / William H. Swatos (eds.), Testing pluralism, globalizing belief, localizing Gods, Leiden, Brill, 2013, p. 57-74.

28. IDEM, „La costellazione delle Chiese ortodosse”, în Enzo Pace (ed.), Le religioni nell'Italia che cambia. Mappe e bussole, Roma, Carrocci, 2013, p. 13-30.

29. IDEM, „Orthodox Christianity in Italy: Historical continuity and social discontinuity”, în Religion, State \& Society, 43 (2015), p. 262-275.

30. GRANERO, Alessandro, „Parrocchia ortodossa romena dell'Esaltazione della Santa Croce", în Quaderni di Benvenuti in Italia, 13 (2018), p. 100-101.

31. GRENET, Mathieu, „Naissance et affirmation d'une nation étrangère entre colonie et groupe de pression: le cas des Grecs à Venise entre le $\mathrm{XV}^{\mathrm{e}}$ et le XVII ${ }^{\mathrm{e}}$ siècle", în Albrecht Burkardt (ed.), Commerce, voyage et expérience religieuse, $X V I^{e}-X V I I I^{e}$ siècles, Rennes, Presses Universitaires de Rennes, 2007, p. 419-438.

32. IDEM, La Fabrique Communautaire. Les Grecs à Venise, Livourne et Marseille, v.1770-v.1830, Roma, École française de Rome / École française d'Athènes, 2016.

33. GuGliELMI, Marco, „Globalization and Orthodox Christianity: A Glocal Perspective", în Religions, 9: 7 (2018), disponibil la https://www.mdpi.com/2077-1444/9/7/216/htm (27.08.2021).

34. HAYDEN, Robert M., „Antagonistic tolerance: Competitive Sharing of Religious Sites in South Asia and the Balkans", în Current Anthropology, 42: 2 (2002), p. 205-231.

35. IDEM, Antagonistic Tolerance: Competitive Sharing of Religious Sites and Space, London / New York, Routledge, 2016.

36. IHLAMUR-ÖNER, Suna Gülfer, ,,Romanian Orthodox Churches in Italy: The Construction of the Romanian-Italian Transnational Orthodox Space", în Maria Hämmerli / Jean-François Mayer (eds.), Orthodox Identities in Western Europe: Migration, 
Settlement and Innovation, London / New York, Routledge, 2014, p. 29-50.

37. Introvigne, Massimo / Zoccarelli, Pier Luigi (eds.), Le Religioni in Italia. La Chiesa Ortodossa Italiana, disponibil la https://cesnur.com/la-chiesa-ortodossa-italiana/ (16.09.2021).

38. MANOUSSACAS, Manoussos, „La comunità greca di Venezia e gli Arcivescovi di Filadelfia", în vol. La Chiesa greca in Italia dall'VIII al XVI secolo, Atti del Convegno storico interecclesiale (Bari, 30 aprile - 4 maggio 1969), t. 1, Padova, Antenore, 1973, p. 45-87.

39. MARCHEI, Natascia, Il "Diritto al tempio". Dai vincoli urbanistici alla prevenzione securitaria, Napoli, Editoriale Scientifica, 2018.

40. Metropolitan of Kykkos and Tylliria NIKIFOROS, The Eccclesial Crisis in Ukraine and its Solution According to the Sacred Canons, Jordanville, New York, Holy Trinity Seminary Press, 2021.

41. MoRINI, Enrico, Gli ortodossi, Bologna, Il Mulino, Edizione Ebook 2010.

42. MoschonAs, Nicholaos G., „La Comunità greca di Venezia: aspetti sociali ed economici", în Maria F. Tiepolo / Eurigio Tonetti (eds.), I Greci a Venezia, Veneția, Istituto Veneto di Scienze Lettere ed Arti, 2002, p. 221-242.

43. PACINI, Andrea, „L'ortodossia in Europa e nel mondo: profilo demografico e organizzazione ecclesiale", în Andrea Pacini (ed.), L'Ortodossia nella nuova Europa. Dinamiche storiche $e$ prospettive, Torino, Edizioni della Fondazione Giovanni Agnelli, 2003, p. 165-184.

44. PAOLINI, Luca, „La tolleranza religiosa garantita ai greci nella Livorno granducale", în Studi Urbinati. Nuova Serie, 57-58/41-42 (1988-1990), p. 217-246.

45. PARLATO, Vittorio, „Gli edifici di culto ortodossi in Italia come testimonianze della fede, delle memorie e cultura di popoli”, în Stato, Chiese e pluralismo confessionale, 32 (2019), p. 126-137.

46. PARLATO, Vittorio, „La legge n. 126 del 2012 relativa ai rapporti tra Italia e Sacra Arcidiocesi Ortodossa d'Italia e Malta", în Stato, Chiese e pluralismo confessionale, 36 (2012), p. 1-19, disponibil la https://www.statoechiese.it/images/uploads/articoli_pdf/parlato 3_la_legge.pdf?pdf=la-legge-n.-126-del-2012-relativa-ai-rapporti -tra-italia-e-sacra-arcidioces (17.09.2021).

47. PORFYRIOU, Heleni, „La diaspora greca in Italia dopo la caduta di Costantinopoli: Ancona, Napoli, Livorno, e Genova", în Maria F. 
Tiepolo / Eurigio Tonetti (eds.), I Greci a Venezia, Veneția, Istituto Veneto di Scienze Lettere ed Arti, 2002, p. 151-184;

48. PORFYRIOU, Heleni, „La presenza greca in Italia: chiese, confraternità e collegi", în Donatella Calabi / Elena Svalduz (eds.), Il Rinascimento italiano e l'Europa, vol. 6. Luoghi, spazi, architetture, Costabissara, Fondazione Cassamarca / Angelo Colla Editore, 2010, p. 567-584.

49. Statutul pentru organizarea și funcționarea Episcopiei Ortodoxe Române a Italiei, disponibil la adresa https://episcopiaitaliei.it/media/statut_eori.pdf (19.09.2021).

50. TAlalay, Mikhail, „Ortodossia russa in Italia”, în Religioni e società, 30 (1998), p. 90-98. 